\title{
Interpreting students' perceptions in fluid mechanics learning outcomes
}

\section{Interpretando las percepciones de los estudiantes en}

\section{los resultados de aprendizaje de mecánica de fluidos}

Filomena Soares 1, Celina P. Leão 1, Anabela Guedes 2, Isabel M. Brás Pereira 2, Cristina Morais², M. Teresa Sena Esteves ${ }^{2}$

Centro ALGORITMI, Escola de Engenharia da Universidade do Minho, Portugal. \{filomena.soares, celina.p.leao\}@algoritmi.uminho.pt ${ }^{2}$ CIETI - Centro de Inovação em Engenharia e Tecnologia Industrial, ISEP - Instituto Superior de Engenharia do Porto, Portugal. \{afg, imp, Icm, mte\}@isep.ipp.pt

\section{Abstract}

The objective of this study is to analyse the impact of introducing a practical work in the learning process of the Fluid Transport Systems course in Chemical Engineering degree. The students, in groups of two or three elements, were free to choose the application case in order to develop the practical work proposed by the responsible teachers. The students selected a centrifugal pump to supply water to houses or buildings and designed the piping system. The practical work was evaluated through the written report. The students' perceptions were analysed through a questionnaire. The learning outcomes were also considered in order to understand how the fluid mechanics concepts were acquired. In the teachers' point of view the teamwork should enable the development of students' soft skills and competencies, promoting the ability to integrate and work in teams. The students changed their learning processing and perception becoming more reflective and less accommodative, forcing them to think critically and share opinions. Regarding the Fluid Mechanics assessment, the practical work increased, in average, the final grade at least one value.

Keywords:

Fluid Mechanics; Learning Styles; Students Perceptions; Engineering Education.
Resumen

El objetivo de este estudio es analizar el impacto de introducir un trabajo práctico en el proceso de aprendizaje del curso Sistemas de Transporte de Fluidos en la carrera de Ingeniería Química. Los estudiantes, en grupos de dos o tres individuos, fueron libres de escoger el tema a desarrollar para llevar a cabo el trabajo práctico propuesto por los profesores responsables. Los estudiantes seleccionaron una bomba centrífuga para surtir agua a las casas o edificios y diseñar el sistema de tuberías.

El trabajo práctico fue evaluado a través del informe escrito. Las percepciones de los estudiantes fueron evaluadas a través de cuestionarios. Los resultados del aprendizaje también fueron considerados para entender cómo los conceptos de mecánica de fluidos fueron adquiridos. Desde el punto de vista de los profesores, el equipo de trabajo debe desarrollar las competencias transversales, promocionando las habilidades para integrarse y trabajar en equipo. Los estudiantes cambiaron sus procesos de aprendizaje y percepción, volviéndose más reflexivos y más proactivos, forzándolos a pensar de forma crítica y a compartir sus opiniones. Con respecto a la evaluación de la Mecánica de Fluidos, el trabajo práctico incrementó la nota final, de media, al menos un punto

\section{Palabras Clave:}

Mecánica de Fluidos; Estilos de Aprendizaje; Percepción Estudiantil; Educación en Ingeniería. 


\section{Introduction}

Several analysis and changes have been proposed to the traditional teaching/learning methodologies. The student is now considered the centre of this process where he/she has an active participation. News methodologies that encourage teamwork were promoted and adopted in schools in the first academic years preparing students for teamwork in order to assure a correct working performance at present and in future profession (Alves, Moreira, Mesquita, and Fernandes, 2012). With teamwork students face new challenges having the opportunity to reveal their creativity, initiative and develop technical and transversal competencies. No matter what methodology, all process of teaching/ learning require to be assessed, understanding not only what students have learned but also how deeply and if they managed to relate the learned contents. Meanwhile, tools to support and monitoring certain types of interactions with individual performance within the team have been developed reducing the subjectivity and difficulties inherent to this process of assessment of teamwork (Fidalgo-Blanco, Lerís, Sein-Echaluce, and García-Peñalvo, 2015; Fidalgo-Blanco, SeinEchaluce, García-Peñalvo, and Conde, 2015). Other new tools and strategies are proposed: the availability of e-books (Brito, Soares, and Leão, 2012), virtual laboratories, offering mathematical simulations and graphical animations (Lemos, Carvalho, Soares, Leão,
Fernandes, and Rodrigues, 2008), remote laboratories, sharing material and human resources (Gomes, and Bogosyan, 2009), educational platforms (Vázquez-Martínez and Alducin-Ochoa, 2014), among others. The use of the Internet and the availability of wireless communication in campus allow the implementation of such tools, optimizing resources, space and time.

Especially important for engineering students is the paradigm "Learning by Doing" (Hansen, 1990). There are available several web laboratories (working in virtual environment with mathematical and/or graphical simulators or implementing remote experimental rigs with real-world problems) (Bagnasco, Parodi, Ponta, and Scapolla, 2005; Carnevali, and Buttazo, 2003; Coito, Almeida, and Palma, 2005; Nedic, Machotka, and Nafalski, 2003; Alves, Marques, Viegas, Costa Lobo, Barral, Couto, Jacob, Ramos, Vilão, Covita, Alves, Guimarães, and Gustavsson, 2011; Zubía and Alves, 2011).

In this new teaching/learning process and tools' definition, the students' learning styles have been the focus of some research studies. Kolb's experiential learning theory is a well-known educational theory in the higher education cycle (Silva, Pereira, Soares, Leão, Machado, and Carvalho, 2014). Knowledge, skills or attitudes are achieved through confrontation among some modes of experiential learning (Kolb, 1984). The 
model works on two levels or two learning activities, perceiving and processing, and Kolb emphasizes four distinct learning styles (accommodating, diverging, assimilating and converging) based on four learning stages (Kolb, 1984; Kolb, and Kolb, 2005). A typical representation of the two Kolb's learning activities is based on two axes (Figure 1): the horizontal axis corresponds to the measurement of the processing activity, the way how we approach a situation, ranging from the active experimentation to the reflective observation; and the vertical axis to the measurement of the perceiving activity by distinguishing between the concrete experience and the abstract conceptualization, quantifying the emotional response or the way of thinking. The learning styles are the combination of two lines of the axes (Kolb, and Kolb, 2005).

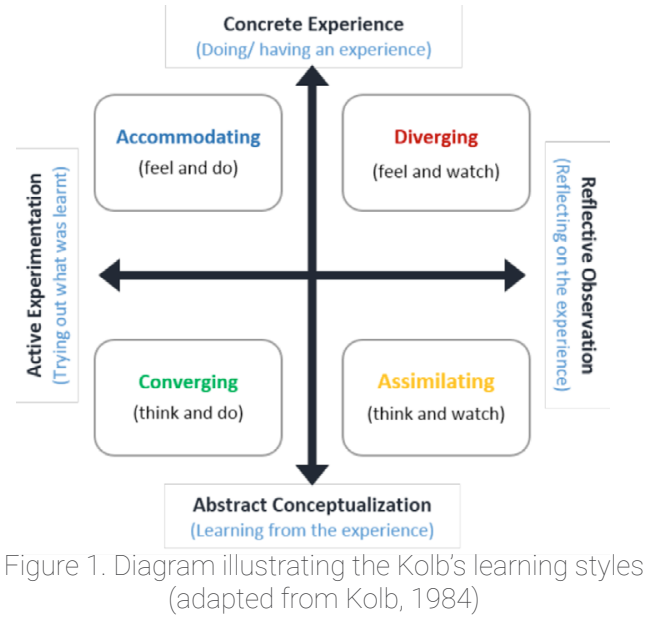

Following this trend and regarding in particular the case of fluid mechanics teaching/learning activities, several authors have proposed new educational tools.

Usually, students have difficulties with fluid mechanics concepts and theories. Fraser, Pillay,
Tjatindi, and Case (2007) reports the results of a study on the impact of using computer simulations to teach pressure measurements, fluid flow through pipes with changing diameter, and fluid velocity profiles between flat plates. These difficulties were assessed using questions from the Fluid Mechanics Concept Inventory (FMCI) developed by Martin, Mitchell, and Newel, (2003). Most of the students in the fluid mechanics class participated in the experiment. Students gave a positive feedback, showing significant improvements in two of the three areas of difficulty.

eMersion project (Gillet, Fakas, 2001) enforces hands-on learning activities and adds flexibility in the curricula. It is an online collaborative environment with remote access to experimentation facilities, webbased simulation capabilities, and availability of theoretical concepts. Three pedagogical scenarios are developed: automatic control, fluid mechanics, and biomechanics. In fluid mechanics, flows behaviours and the simulation techniques are studied, providing the students with virtual experimentation setups. A virtual wind tunnel was designed with various wing profiles and alternative simulation algorithms. 1D phenomena and $2 \mathrm{D}$ flows or shockwave propagation can be studied.

CFDnet is a simulation program for fluid dynamics running in the Web. Students are allowed to configure, solve and visualize their own case studies. The use of CFDnet in two Canadian universities enables students to test 
multiple cases with a considerable reduction in laboratory expenses (Militzer, Bell, and Ham, 2000).

Settles, Tremblay, Cimbala, Dodson, and Miller, (2006) report the introduction of 10-15 min videos in the handouts in order to illustrate the basic concepts in fluid mechanics. These videos are a complement to the traditional textbooks.

In order to motivate students in fluid mechanics, an innovative pedagogy based on games was implemented (Absi, Nalpas, Dufour, Huet, Bennacer, and Absi, 2011). Students were challenged to seek real-world situations corresponding to fluid mechanics applications and test them in order to verify and validate the theoretical concepts previously acquired. Learning through games promoted the motivation and performance of students, translated in their final evaluation improvement.

The study presented in (Baldock and Chanson, 2006) describes the pedagogical impact of experimental case studies based on real-world problems, included as part of the syllabus Fluid Mechanics, an advanced undergraduate course in an Australian University. The projects were proposed as a complement to the traditional classes and preparing students to the challenges of professional design, systems' modelling, collecting and analysing data. The mathematical modelling of physical systems combines the experimental, analytical and numerical work in order to develop students' abilities to solve real-world problems. The process adopted is based on the projectbased learning and collaborative work as a complement to tutorial traditional teaching. The evaluation of the course includes oral presentations, peer reviewed and written reports, which aim to maximize the reflection and student development.

This article reports the introduction of a practical work as a part of the students' assessment in the course of Fluid Transport Systems from the Chemical Engineering graduation of the of the Instituto Superior de Engenharia do Porto (ISEP). The analysis was based on the feedback from the students of the first and second cycles through a questionnaire. Students' learning styles were also identified before and after the execution of the practical work. Special attention was paid to the promotion of student's soft skills, a key issue in their future professional career. The article is divided in six sections, including the introduction. In section 2 Fluid Mechanics curricular unit is characterized; section 3 presents the proposed practical work and the students' outcomes; the evaluation tools are detailed in section 4 . Results are analysed and discussed in section 5 and the final remarks are addressed in section 6 . 


\section{Teaching fluid mechanics in chemical engineering}

Fluid Mechanics is an important subject in Chemical Engineering syllabus. In ISEP there are two cycles of Chemical Engineering graduation, First Cycle (3 years) and Masters (2 years) representing two independent but complementary levels of formation and skills development. The first cycle enables students to gather technical and scientific tools that will allow them to act in industry, control and laboratory services. The Master degree provides a deepening of knowledge in the fundamental areas of chemical engineering

\subsection{Course Characterization}

Fluid Transport Systems is a course of the second year of the first cycle in Chemical Engineering of ISEP It has a total of four hours per week (one hour of lectures and three hours of practical classes). There are daytime and evening classes with an average total number of 85 enrolled students. Lectures are mainly expositive but also use the interrogative method and different demonstrative and

\subsection{Course Objectives}

Fluid Transport Systems has the general objective of giving students the fundamental knowledge in fluid mechanics that will enable them to design fluid transport systems and select the associated equipment. At the end of and offers specific subjects in one of two branches presently available: environmental protection and energy optimization in chemical industry.

Fluid Mechanics is one of the areas covered in both cycles of Chemical Engineering, and mainly in two courses: Fluids Transport Systems (1st cycle) and Transport Phenomena (2nd cycle).

The present study refers to Fluids Transport Systems course.

active techniques. Students are requested to follow joint problems and concrete cases solving. Active methods, mainly learning based in problems and real cases solving, are the selected techniques for practical classes. In this course students get the fundamental knowledge of fluid transport, and skills to use in project engineering of fluid transport systems.

this course, students should be able to make mass and energy balances that are necessary to design systems and select the appropriate equipment (flow meters; centrifugal, reciprocating and rotary pumps; compressors 
and fans). Those balances are performed for incompressible and compressible fluids, either

\subsection{Course Syllabus}

The syllabus of this course is divided in two main parts. The first one covers the fundamental principles of mass, energy and momentum transport and the second

\subsection{Course Assessment}

In Fluid Transport Systems, students may choose between two ways of assessment: with two individual Tests (T1 and T2) and a practical work $(\mathrm{PW})$ or a final exam (FE) and the practical work. In both cases, the practical work has a weight of $20 \%$ in the in steady and unsteady states.

part includes the systems of fluid transport (selection and sizing of pipes, valves and fittings, flow meters, pumps, compressors and fans).

\subsection{Course Learning Outcomes}

It is expected that at the end of the course students can identify and understand the fundamental phenomena associated with fluid mechanics (statics, dynamics of Newtonian fluids). The students should also understand energy conversions, and how to calculate energy/head losses and the energy/pressure necessary for fluid transport in specific situations. In terms of engineering practice, systems.

\section{Case-study in fluid transport systems' course}

In the practical work students must apply the concepts acquired in the theoretical lectures to a case study of real-world. The final grade. Therefore, in case the students decide to take the final exam it has a weight of $80 \%$, otherwise $\mathrm{T} 1$ and $\mathrm{T} 2$ have a weight of $40 \%$ each on the final grade. There is no minimum score in any of the assessment components.

the students should be able to select and design fluid transport systems and associated equipment (pipes, valves, flow meters, pumps, fans, compressors), and understand their operation. With the completion of the proposed PW students should acquire skills and competencies to integrate teams of design/optimization of fluid transport

PW aims to apply knowledge acquired in the second part of the syllabus, in particular the selection of centrifugal pumps. 


\subsection{The Practical Work}

The PW is proposed by the responsible teacher of the course and the theme is Replacing a centrifugal pump in the water supply system of a building/independent house. The various systems of water supply are presented to students during classes and they are free to choose the type of application system. Students may choose to work individually or in groups of 2 or 3 elements. The work is mandatory and must be developed outside class time. The students can discuss options with the teachers of the course during classes

\subsection{Students' Solutions}

Below are presented some schemes of water supply to independent houses (Figures 2 to 5 ) and to buildings (Figures 6 and 7) that were described by the students in the practical work proposed in the course.
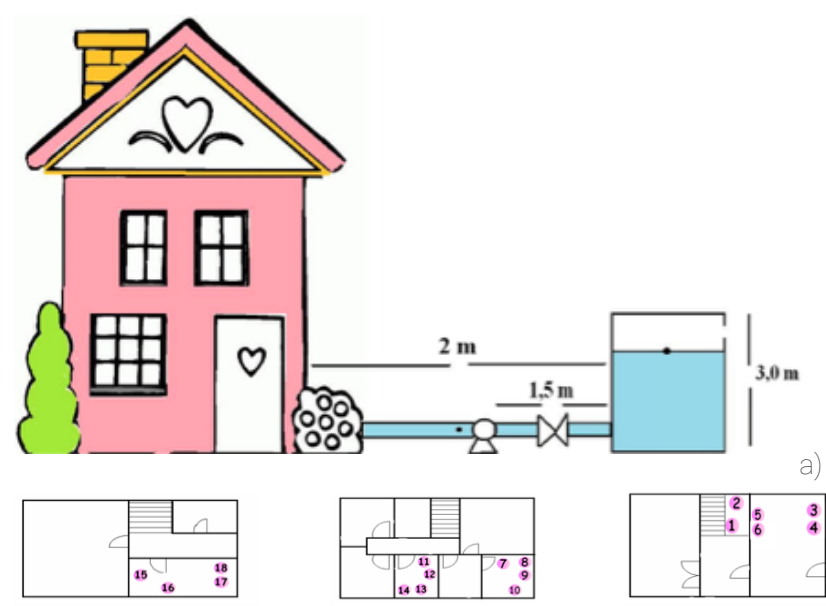

Figure 2. Scheme of a water supply system: from a reservoir with an external centrifugal pump to an independent house with 3 floors (a); plan of the ground floor (b); plan of the $1^{\text {st }}$ floor $(c)$; plan of the $2^{\text {nd }}$ floor (d) (Sousa, and Rodrigues, 2012) or at other times set for this purpose. Students have diverse bibliography of support for carrying out the work (Munson, Young, and Okiishi, 1994) that can be found in Moodle (information support site of the courses) or in the library. The work starts after $75 \%$ of classes taught and must be delivered at the end of the semester in the form of a written report in accordance with instructions available in Moodle.

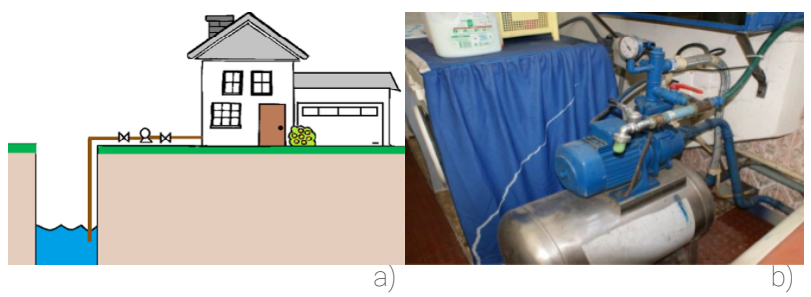

Figure 3. Scheme of a water supply system: from a well with an external centrifugal pump to an independent house with 2 floors (a); photo of the pump that broke down and must be replaced (b) (Cerqueira, Saraiva, and Mendes, 2011)

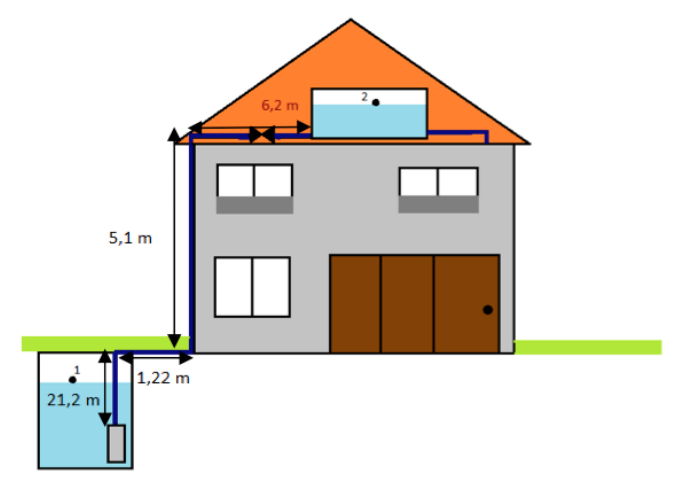

Figure 4. Scheme of a water supply system: from a hole $(20 \mathrm{~m}$ deep) with a submersible centrifugal pump to a reservoir in an independent 2 floors' house (Fonseca, and Carmo, 2014) 

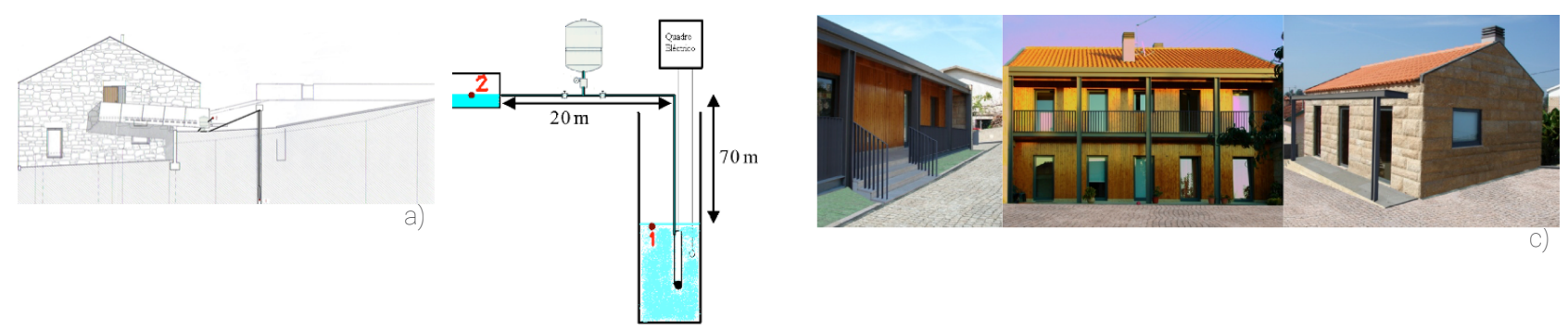

Figure 5. Scheme of a water supply system: from a hole (70 $\mathrm{m}$ deep) with a submersible centrifugal pump to an independent house with 2 floors and outhouse: house, hole and reservoir (a); detail of the supply system: pump, piping and reservoir (b); view of the house (front, back, outhouse) (c) (Ribeiro, and Martinho, 2012)

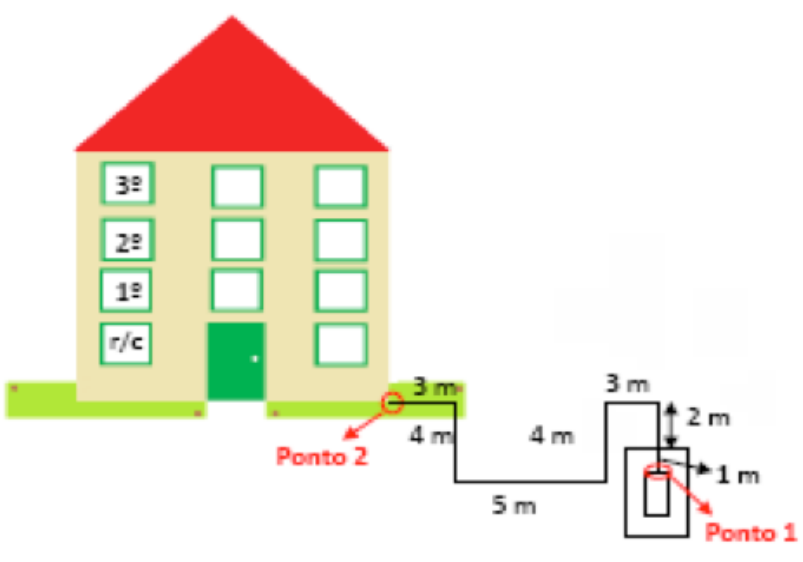

Figure 6. Scheme of a water supply system: from a well with a submersible centrifugal pump to a building with 4 floors and 25 houses (Martins, and Azevedo, 2014)

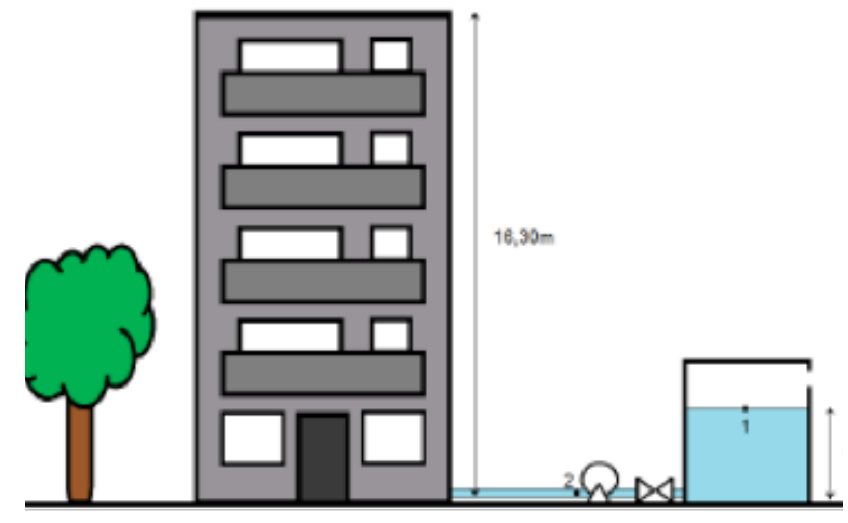

Figure 7. Scheme of a water supply system: from a reservoir with an external centrifugal pump to a building with 5 floors and 5 houses (Maia, and Sousa, 2011)

\section{Evaluation tools}

In this section the research hypotheses defined (material and methods) are presented. for this study and the methodology applied

\subsection{Research hypotheses}

In order to analyse the impact of introducing a practical work in the learning process of the facilitates the acquisition of fluid mechanics Fluid Transport Systems course in Chemical concepts;

Engineering degree two hypotheses were H2 - The introduction of the practical work formulated: increases the final grade in Fluid Transport

H1 - The introduction of the practical work Systems course.

\subsection{Material and Method}


The data were collected through a questionnaire handed out to students during laboratory classes and after a test, in the 2nd semester of 2013/14 academic years. Note that the questionnaires were answered on a voluntary basis.

In order to obtain a representative sample, students who attended this course in previous school years were also considered, including students from both cycles of studies (1st cycle and 2nd cycle or Master degree). Students took 5 to 10 minutes to complete the questionnaire. A total of 162 students participated in the study, $85.2 \%$ from BSc and $14.8 \%$ from MSc in Chemical Engineering. From those $85.2 \%$ attending BSc, $0.6 \%$ were in the 1 st year, corresponding to students enrolled in advance, $45.1 \%$ in the 2nd year, corresponding to the academic year of the course and $39.5 \%$ in the 3rd year, corresponding to students that finished the course at least one year before. In the $14.8 \%$ from MSc in Chemical Engineering, $11.1 \%$ were in the 1 st year and $3.7 \%$ in the

\subsection{Questionnaire applied}

The questionnaire aimed to identify and assess the students' perceptions with the development of the practical work within the course. The answers obtained contributed to assess the added value of the work not only to knowledge acquisition but also in improving the effectiveness of the course. The questionnaire was based on previous studies 2nd year (Figure 8). The students from the MSc had attended the course at least two or three years before. The students attended the course in different timetables $(73.1 \%$ in the day time and $26.9 \%$ after working hours). $84.8 \%$ of all those students have attended the course once and only $1.9 \%$ have attended the course more than 3 times. Most of the students $(51.1 \%)$ are female. The average age is 22.25 years $(\mathrm{SD}=3.52$ range $19-51$ years) and most of the students (54.9\%) are aged 21 years or less. For the majority of the students (73.1\% - $47.4 \%$ in day time classes and $25.7 \%$ in evening classes) it was the first time that they held a practical work of this kind.

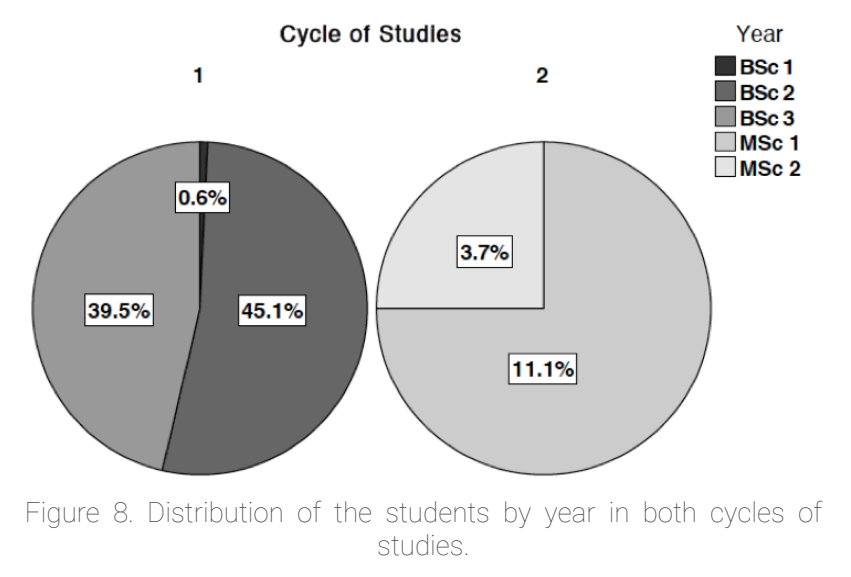

(Barros, Leão, Soares, Minas, and Machado, 2013; Soares, Leão, Carvalho, Vasconcelos, and Costa, 2014) uniquely with an update and contextualization of some questions to the topic under discussion. Subsequently, the questionnaire was pre-assessed within a group of students in order to identify any ambiguous issue and small bugs (Guedes, 
Esteves, Morais, Soares, and Leão, 2014).

The questionnaire comprises several parts in order to characterize the student and to assess the practical work developed. Thus, after the identification of the questionnaire purpose, the first part includes general questions to identify the respondent student (gender, age, academic year, classes' timetable, number of times that has attended the course).

The questionnaire also allows the knowledge of the student' perception regarding his own learning style and identifies the learning style that the student uses during the development of the practical work. The learning styles used were based on the theory of Kolb (Kolb, 1984; Kolb, and Kolb, 2005).

For the assessment of technical skills acquired through the practical work, a set of questions/statements was defined and evaluated according to a 5-levels Likert scale (1 - Very Poor, 2 - Poor, 3 - Average, 4 Good, 5 - Very Good):

TS1 - Rate the practical work as a useful tool in supporting the course;

TS2 - This practical work provides a better understanding of the course contents;

TS3 - In general, I can say that the accomplishment of the practical work helped me to grasp the concepts transmitted throughout the semester;

TS4 - In general, I can say that the accomplishment of the practical work made my learning more objective;

And some open questions and questions of Yes/No were also included:

TS5 - The practical work motivated me to learn the contents of the course?

TS6 - I believe that the practical work should be less driven by the teacher? Identify why.

As the practical work uses a real-world case for a better understanding of the syllabus of the course, a group of sentences aiming the assessment of the concept understanding was also included:

CU1 - I am able to select a pump and design the surrounding system (pump characteristics and system costs,...) for any situation;

CU2 - I am able to select a pump and design the surrounding system (pump characteristics and system costs,...) for a house/building; CU3 - I am able to select a pump (pump characteristics, costs,...) for any situation;

CU4 - I am able to select a pump (pump characteristics, costs,...) for a house/building; CU5 - I am not able to select a pump and design the surrounding system (pump characteristics, costs,...) for a house/building. Several soft skills were also evaluated considering a 5-levels Likert scale of agreement (1 - strongly disagree, 2 - disagree, 3 - neither agree nor disagree, 4 - agree, 5 strongly agree):

The development of the practical work allowed to:

SS1 - Stimulate collaborative work;

SS2 - Stimulate my intellectual curiosity;

SS3 - Provide knowledge to my study field;

SS4 - Relate this Curricular Unit to others;

SS5 - Apply the acquired concepts in other

Curricular Units.

In the following section obtained results are presented and discussed. 


\section{Evaluation tools}

Whenever relevant, the results hereinafter are presented by cycle of studies. For the statistical analysis a significance level of $5 \%$ was used. When appropriate and due

\subsection{Questionnaire analysis}

It is interesting to note that most of the students $(80.5 \%)$ identify their learning style (in process and perception) as accommodating. Students learn through practical situations that propose challenges' solving. During learning process, students exchange opinions with colleagues in order to build the final idea (Souza, Lima, Costa, Santos, Junior, and Penedo, 2013). Another group of students $(8.2 \%)$ identified themselves with the converging style in which learning is concerned with the creation of concepts. For both styles, students perform things by active experimentation, as shown in Figure 9 (a). $8.5 \%$ of the students identified their learning style as diverging. This means that they prefer to watch rather than to do, looking at things from different perspectives. The students that can be responsible for such behaviour are mainly students of the 2nd cycle of studies (Figure 9(c)).

Regarding the technical skills acquired through the practical work development some of the statements/questions in the questionnaire were analysed. TS1, TS2, TS3 and TS4 were answered according to the to the nature of the variable in study, nonparametric test (Wilcoxon Signed Ranks Test, W) was used as a test for statistical significance.
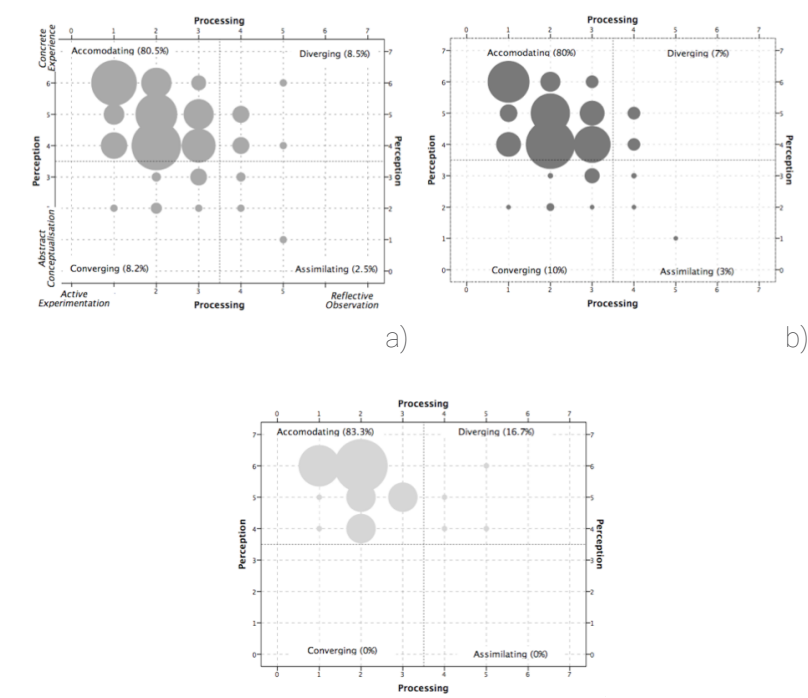

Figure 9. Learning styles representation identified by (a) all respondent students; (b) 1st cycle students; (c) 2nd cycle students (based on the theory of Kolb, 1984).

satisfaction 5-levels Likert scale, where 1 represents Very Poor and 5, Very Good. TS5 and TS6 are Yes/No questions.

The analysis of the answers to each of these statements/questions showed interest and motivation among students to this kind of encouragement and practice (Figure 10). The results represent a positive opinion of the majority of the students $(75 \%$ with $4-$ "Good" and 5 - "Very Good") about the four statements (Figure 10(a)). The answers show that the practical work was a useful tool for supporting subjects taught on the scope of 
the course, improving their understanding. It is interesting to note that students, although motivated, consider that the teachers should guide the PW (Figure 10(b)).

Qualitatively analysing the answers given by the students to the TS6 question the most common reasons stated were:

"All the support given by the teacher is important",

"The help of the teacher is crucial/essential" because "the student may not understand the objectives of the work" and,

"The help/assistance of the teachers allows a better assimilation of the knowledge concerning this topic".

Students of the 2nd cycle of studies have a more objective opinion:

\section{"... learning implies making mistakes and correcting} them and, if so, guidance is most helpful"

Regarding Concept Understanding, five situations were established to understand if the purpose of the practical work was completed, i.e., if the use of a real world case
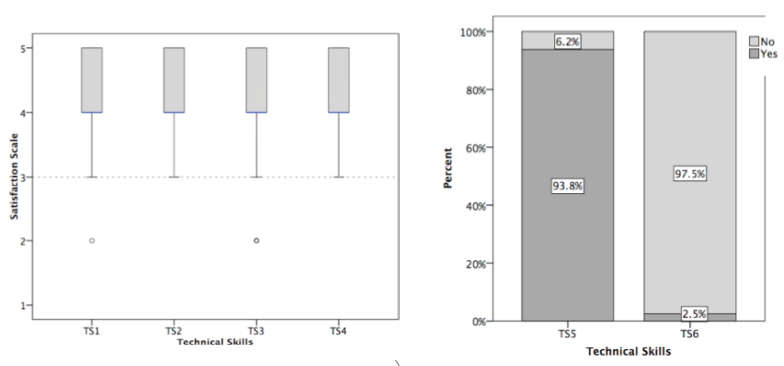

Figure 10. Respondent students' assessment of some technical skills

allows a better understanding of the syllabus of the course.

To select a pump and design the surrounding system (pump characteristics and system costs,...) for a house/building (CU2) was the most chosen situation by students (39\%). This choice somewhat confirms the view expressed by students when they indicate that the practical work should be supervised by the teacher. The concept understood by students corresponds to the general objective of the practical work: students are able to select a pump and design the surrounding system for a house/building corresponding to a real world case. That group was followed by $26.6 \%$ of the students that said they could select and design a pump for any other situation (CU1). Only $2.6 \%$ of the students indicated not being able to select a pump and design the surrounding system. This percentage corresponds to the $3 \mathrm{rd}$ year students of the first cycle that attend evening classes.

The identification of the learning style used by the students during the implementation of the PW demonstrates that $62.7 \%$ of them considered having an accommodating style (Figure 11(a)), while 16.1\% identify their learning style as assimilative.

These results compared to the learning styles identified by students (Figure 9) show some differences, especially in process activity. Some students feel that the learning
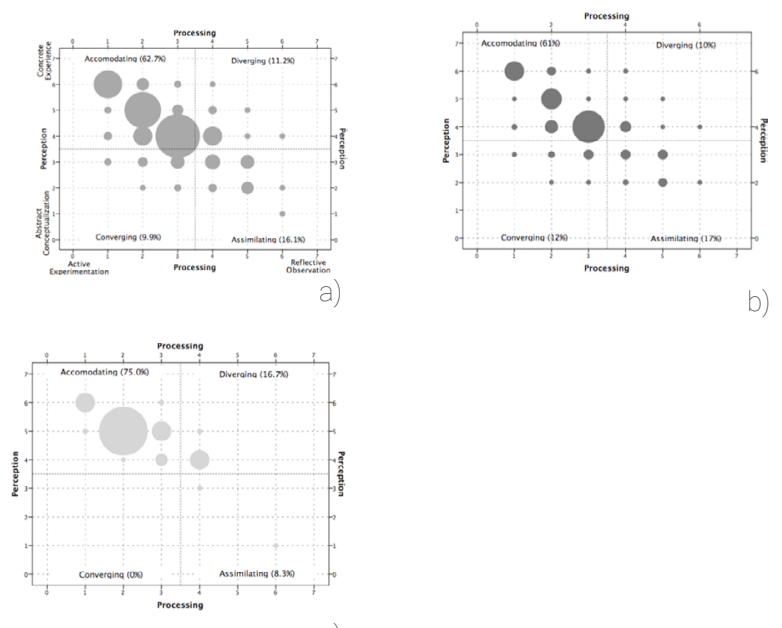

Figure 11. Learning styles representation identified as used during the implementation of the PW by (a) all respondent students; (b) 1 st cycle students; (c) 2nd cycle students (based on the theory of Kolb, 1984) 
process during the implementation of the practical work became more reflective, and not as active as they think it would be. Such feeling may be due to the fact that some students had to search, choose and determine characteristics, sharing their thoughts with the group colleagues. Note that during the implementation of the practical work, course teachers supervised the students that need to follow rules in order to successfully accomplish the final report.

On average, the learning styles identified by the students relating to what they are (2.2 and 4.6 , respectively for processing activity and perception) and what they say have applied during the accomplishment of the PW (2.8 and 4.2, respectively for processing activity and perception), lie in the accommodating region. However, the differences between what students think they are, and what they consider to be during the development of the PW, both for processing or perception, are statistically significant $(\mathrm{W}(156)=4.58$, $\mathrm{p}<0.001$ for processing, $\mathrm{W}(157)=4.44$, $\mathrm{p}<0.001$ for perception). Notice that, the assimilating learning style increases from $2.5 \%$ (Figure 9(a)) to $16.1 \%$ (Figure 11(a)) and, with opposite behaviour, the learning style accommodating decreases from $80 \%$ (Figure 9(a)) to $61 \%$ (Figure 11(a)). This means that although it is considered an active experience, it takes a slightly more abstract conceptualization, where understanding requires reflection to build concepts (Kolb, 1984).

With respect to topic of soft skills the obtained data is summarized in Figure 12.

Accordingly and in average, students show agreement concerning the five sentences regarding the soft skills (agreement higher than 3), however widely dispersed (ranging from 1 - strongly disagree to 5 - strongly agree), except for SS_3 where students expressed a positive opinion on that $\mathrm{PW}$ allowed to provide knowledge to their study field $(\min =3$, and $75 \%$ higher and equal to 4).

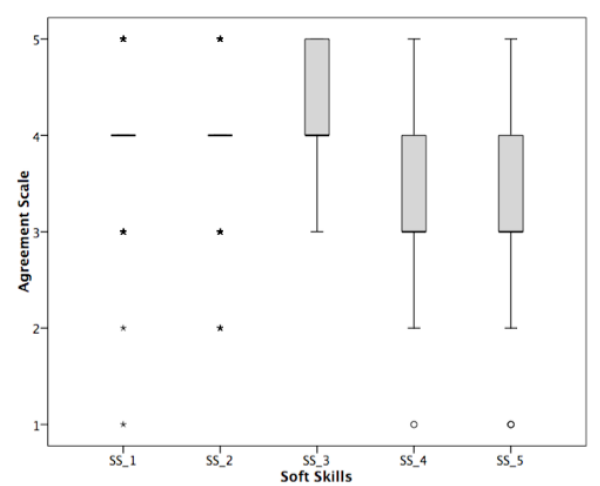

\begin{tabular}{|c|c|c|c|c|}
\hline Soft Skills & $\min$ & $\max$ & Mean & SD \\
\hline SS_1 & 1 & 5 & 4.04 & 0.66 \\
\hline SS_2 & 1 & 5 & 3.96 & 0.72 \\
\hline SS_3 & 3 & 5 & 4.11 & 0.68 \\
\hline SS_4 & 1 & 5 & 3.48 & 0.89 \\
\hline SS_5 & 1 & 5 & 3.37 & 0.83 \\
\hline
\end{tabular}

Figure 12. Respondent students' assessment of some soft skills

\subsection{Learning Process Outcomes}

It is the teachers' belief that the identification of the main purpose and objectives of the 
practical work can be used as a means of students' learning. The students take on a more active role in their learning process throughout the semester, in an indirect way, become more involved, responsible and motivated to the course. The students were quite open to this initiative, revealing a positive performance in the implementation of their educational transformation. However the rate of final approval basically underwent no change.

Through the distribution of final grades (range: 0 to 20) with and without practical work (Figure 13), it can be said that, on average, there has been an increase up to one value in the final grade by considering the practical work comparing with the final grade without considering the practical work, $\mathrm{PW}(\mathrm{W}(148)=1.37, \mathrm{p}>0.05)$ (dashed horizontal line representing the average final grade obtained without the practical work and continuous horizontal line representing the mean final grade including the practical work). This result is very positive showing

\section{Final remarks}

In this study the perceptions of students of two different cycles of studies, related to the use of a practical work as a supplement tool in the teaching/learning process in the course of Fluid Transport Systems of the first cycle in Chemical Engineering, Instituto Superior de Engenharia were analysed.

Since this is a course with a strong theoretical that the use of PW in courses with a strong theoretical component in engineering is quite positive.

It is interesting to observed that without $\mathrm{PW}$ $73 \%$ of the evaluated students pass (grade higher or equal to 9.5 ), increasing to $96 \%$ with the PW, final grades from 10 to 13 , $48 \%$ and $72 \%$, respectively. This difference disappears with the increase in the final grade, i.e., final grades equal to or greater than 16 was obtained for $8 \%$ of students.

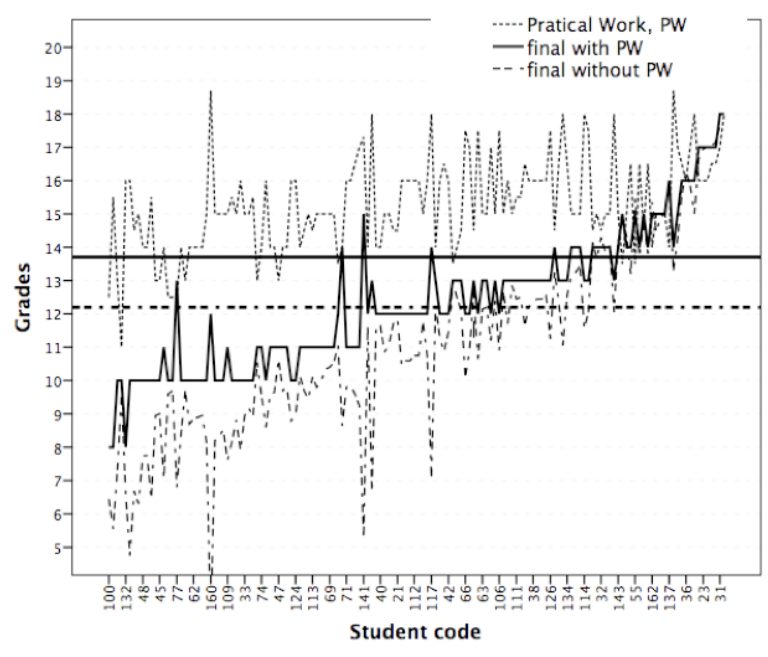

Figure 13. Grades obtained at the end of the semester (two horizontal lines representing the average final grade obtained without the practical work (dashed line) and the mean final grade including the practical work (continuous line))

component, the main goal of the practical work was to allow students to be able to establish relationships between theory and practice. A real world case application was chosen. Based on the perceptions of students, it can be concluded that the objectives proposed by the practical work have been met. The learning process of the students 
became more reflective making it necessary For the majority of the students $(73.1 \%$ to think and share opinions.

- $47.4 \%$ in day time classes and $25.7 \%$ in Regarding the students assessment, the evening classes) it was the first time that practical work, in average, increased the final they held a practical work of this kind. grade in at least one value.

\section{Acknowledgments}

The authors would like to thank the students

Tecnologia Industrial) and FCT - Fundação for their participation in the study. The para a Ciência e Tecnologia in the scope of authors also thank the Research Centre the project PEst2015-2020 reference UID/ CIETI (Centro de Inovação em Engenharia e CEC/00319/2013 for all the support provided.

\section{References}

Absi, R., Nalpas, C., Dufour, F., Huet, D., P. S., and Gustavsson, I. (2011). Using Bennacer, R. and Absi, T. (2011). Teaching VISIR in a large undergraduate course: Fluid Mechanics for Undergraduate Students Preliminary assessment results. 2011 IEEE in Applied Industrial Biology: from Theory Global Engineering Education Conference to Atypical Experiments. Int. Journal of (EDUCON) - "Learning Environments and Engineering Education, 27(3), 550-558. Ecosystems in Engineering Education", Amman, Jordan, April 4 - 6, 2011 (pp.

Alves, A. C., Moreira, F., Mesquita, D., and 1125-1132). doi: http://dx.doi.org/10.1109/ Fernandes, S. (2012). Teamwork in ProjectEDUCON.2011.5773288.

Based Learning: engineering students' perceptions of strengths and weaknesses. Bagnasco, A., Parodi, G., Ponta, D., and Proceedings of the Fourth International Scapolla, A. M. (2005). A Modular and Symposium on Project Approaches (PAEE), Extensible Remote Electronic Laboratory. S. Paulo, July 26-27(pp. 23-32). International Journal of Online Engineering, $1(1)$.

Alves, G. R., Marques, M. A., Viegas, C,

Costa Lobo, M. C., Barral, R. G., Couto, Baldock, T. E., and Chanson, H. (2006). R. J., Jacob, F. L., Ramos, C. A., Vilão, Undergraduate Teaching of Ideal and Real G. M., Covita, D. S., Alves, J., Guimarães, Fluid Flows: The Value of Real-World 
Experimental Projects. European Journal of EngineeringEducation, 31(6),729-739.http:// dx.doi.org/10.1080/03043790600911837

Barros, C, Leão, C. P., Soares, F., Minas, G., and Machado, J. (2013). Students' perspectives on Remote Physiological Signals Acquisition Experiments. Proceedings of CISPEE, ISEP, Porto, Portugal, October 31

- November 1. http://dx.doi.org/10.1109/ cispee.2013.6701975

Brito, J., Soares, F., and Leão, C. P. (2012). Digital Control iBook: A Flashier Way to Study. Proceedings of the ASME International Mechanical Engineering Congress \& Exposition, IMECE2012, v. 5: Education and Globalization; General Topics, Houston, Texas, USA, November 9-15 (pp. 69-73). http://dx.doi.org/10.1115/imece2012-87511

Carnevali, G., and Buttazo, G. A. (2003). Virtual Laboratory Environment for Realtime Experiments. Proceedings 5th IFAC International Symposium on Intelligent Components and Instruments for Control Applications, Aveiro, Portugal, July 9-11 (pp. 39-44).

Cerqueira, A. S., Saraiva, C., and Mendes, A. (2011). Substituição de uma bomba centrífuga no sistema de abastecimento de água a uma habitação, Instituto Superior de Engenharia do Porto, Students' Report (in Portuguese).
Coito, F., Almeida, P., and Palma, L. B. (2005). SMCRVI-A Labview/Matlab Based Tool for Remote Monitoring and Control. Proceedings of the 10th IEEE Conference on Emerging Technologies and Factory Automation (Volume 2), Catania, Italy, 1922 September (pp. 1039-1044). http://dx.doi. org/10.1109/ETFA.2005.1612786

Fidalgo-Blanco, Á., Lerís, D., SeinEchaluce, M. L., and García-Peñalvo, F. J. (2015). Monitoring Indicators for CTMTC:

Comprehensive Training Model of the Teamwork Competence in Engineering Domain. International Journal of Engineering Education (IJEE), 31(3), 829-838.

Fidalgo-Blanco, Á., Sein-Echaluce, M. L., García-Peñalvo, F. J., and Conde, M. Á. (2015). Using Learning Analytics to improve teamwork assessment. Computers in Human Behavior, 4\%, 149-156. doi:http://dx.doi. org/10.1016/j.chb.2014.11.050.

Fonseca, C., and Carmo, V. (2014). Substituição de uma bomba centrífuga numa habitação, Instituto Superior de Engenharia do Porto, Students' Report (in Portuguese).

Fraser, D.M., Pillay, R., Tjatindi, L., and Case, J. M. (2007). Enhancing the Learning of Fluid Mechanics Using Computer Simulations. Journal of Engineering Education, 96(4), 381-388. http://dx.doi. org/10.1002/j.2168-9830.2007.tb00946.x 
Gillet, D., and Fakas, G. (2001). EMERSION:

A New Paradigm for Web-Based Training

in Engineering Education, Proceedings of International Conference on Engineering Education, Oslo, Norway, August 6-10.

Gomes, L., and Bogosyan, S. (2009). Trends in Remote Laboratories. IEEE Transactions on Industrial Electronics, 56(12), 4744-4756. http://dx.doi.org/10.1109/TIE.2009.2033293

Guedes, A., Esteves, M. T. S, Morais, C., Soares F., and Leão, C. L. (2014). Do Papel e Lápis ao Mundo Real: Estudo de Caso no Ensino da Mecânica de Fluidos. Proceedings of COBENGE 2014, Brasil, September, 1619.

Hansen, E. (1990). The role of interactive video technology in higher education: Case study and proposed framework. Journal Educational Technology, 30(9), 13-21.

Kolb, A. Y., and Kolb, D. A. (2005). The

Kolb learning style inventory-version 3.1 2005 technical specifications.

Kolb, D. A. (1984). Experiential learning: Experience as the source of learning and development. New Jersey: Prentice-Hall, Inc.

Lemos, F., Carvalho, N.C., Soares, F., Leão, C.P., Fernandes, T., and Rodrigues, H. (2008). User-centred, dynamic and shared Web sites to support the learning activities for University students - concepts. Proceedings of the ICEE08, Pecs and Budapeste, Hungary.

Maia, J. B., and Sousa, J. P. (2011). Substituição de uma bomba centrífuga no sistema de abastecimento de água a um prédio de 4 andares, Instituto Superior de Engenharia do Porto, Students' Report (in Portuguese).

Martin, J. K., Mitchell, J., and Newell, T. (2003). Development of a Concept Inventory for Fluid Mechanics. Proceedings, of the 33rd ASEE/IEEE Frontiers in Education Conference (pp. T3D-23-28). http://dx.doi. org/10.1109/fie.2003.1263340

Martins, D., and Azevedo, M. T. (2014). Substituição de uma bomba centrífuga no sistema de abastecimento de água a uma habitação, Instituto Superior de Engenharia do Porto, Students' Report (in Portuguese).

Militzer, J., Bell, T. A., and Ham, F. E. (2000). CFDnet: A Tool for Teaching Fluid Dynamics over the Internet. Proceedings of TICE 2000: Technologies of information and communication in education for engineering and industry, Troyes, October 18-20, 1\%-21.

Munson, B. R., Young, D. F., and Okiishi, T. H. (1994). Fundamentals of Fluid Mechanics. ( $2^{\text {nd }}$ Ed. $)$. New York: John Wiley \& Sons.

Nedic, Z., Machotka, J., and Nafalski, A. (2003). Remote Laboratories versus Virtual and Real Laboratories, Proceedings of the 
33rd ASEE/IEEE Frontiers in Education Automation and remote control laboratory: Conference, Boulder, CO, November 5-8 (pp. A pedagogical tool. International Journal of T3E1-T3E6). http://dx.doi.org/10.1109/ Electrical Engineering Education, 51(1), 54fie.2003.1263343 67. http://dx.doi.org/10.7227/IJEEE.51.1.5

Ribeiro, D., and Martinho, S. (2012). Sousa, A., and Rodrigues, N. (2012). Substituição de uma bomba centrífuga no Substituição de uma bomba centrífuga no sistema de abastecimento de água a uma sistema de abastecimento de água a uma habitação, Instituto Superior de Engenharia habitação, Instituto Superior de Engenharia do Porto, Students' Report (in Portuguese). do Porto, Students' Report (in Portuguese).

Settles, G. S., Tremblay, G., Cimbala, Souza, G. H. S, Lima, N. C, Costa, A. C. J. M., Dodson, L. J., and Miller, J. D. S., Santos, P. C. F., Junior, J. F. V. P., (2006). Teaching Fluid Mechanics with and Penedo, A. S. T. (2013). Estilos de Flow Visualization Videos. Proceedings of Aprendizagem dos Alunos Versus Métodos the 12th International Symposium on Flow de Ensino dos Professores do Curso de Visualization, German Aerospace Center Administração. Proceedings of the XXXVII (DLR), Göttingen, Germany. Encontro da ANPAD, Rio de Janeiro, Brasil.

Silva, M., Pereira, F., Soares, F., Leão, C. P., Vázquez-Martínez, A. I. and Alducin-Ochoa, Machado, J., and Carvalho, V. (2014). PAIR: J. M. (2014). Blended Learning e Ingeniería: The Remote Industrial Automation Trainer. nivel de uso, rendimiento académico y Proceedings of the ASME 2014 International valoración de los alumnos. Education in the Mechanical Engineering Congress \& Knowledge Society (EKS), 15(3), 120-148. Exposition, IMECE2014, Montreal, Canada, November 14-20.

Zubía, J. G. and Alves G. R. (eds.) (2011). Using Remote Labs in Education - Two Little

Soares, F., Leão, C.P., Carvalho, V., Ducks in Remote Experimentation, Bilbao: Vasconcelos, R. M., and Costa, S. (2014). University of Deusto. 